\title{
Line 125
}

\section{"Those are pearls that were his eyes": Shakespeare's Tempest}

\begin{abstract}
$\mathrm{T}$ he thoughts of the man in the bedroom express deadness in a variety of ways. When the woman asks what he's thinking, he responds: "I think we are in rats' alley / Where the dead men lost their bones" (WL 115-16). When the woman asks about a noise, he responds with a phrase, "The wind under the door" (WL 118), that in Webster refers to the fading breath of an injured man. And when the woman asks whether he remembers anything, the man responds: "I remember / Those are pearls that were his eyes" (WL 124-25). This is the second time Eliot uses this line from the dirge Ariel sings to Ferdinand in The Tempest, reminding us again of a corpse underwater that is not decomposing but being imaginatively fashioned into a piece of underwater sculpture.

"[R]ats' alley / Where the dead men lost their bones" is a landscape of the dead, an evocation of Great War trenches. "The wind under the door" refers to the breath of the victim of a murder attempt. And "Those are pearls that were his eyes" points toward individual bereavement: a young prince listening to a song about the corpse of his father. The three spaces-Shakespeare's magical island with its ethereal music, a room where surgeons bribed by an assailant ignore the gasps of his victim, and the Western front with its mud, rats, and corpses-are layered together in a bedroom conversation where we see not intimacy but disconnection. Awareness of this layering highlights the distance between the false deaths of Shakspeare's Alonso and Webster's Contarino and the real deaths of thousands of British soldiers-between the eventual joy and coupling that winds up The Tempest, the intricate trial scene that winds up The Devil's Law Case, and the malaise and alienation illustrated here in the bedroom of Eliot's poem.
\end{abstract}

